\title{
Effect of Adding Cassava Peel and Lactic Acid Bacteria as a Feed Additive to the Weight of Immune Organs of Super Native Chicken
}

\author{
P. Ardiansyah, E. Suprijatna and S. Kismiati \\ Department of Animal Husbandry, Faculty of Animal Husbandry and Agriculture, \\ Diponegoro University, Semarang, 50275 \\ Corresponding author: panduardiansyah@gmail.com
}

\begin{abstract}
This study aims to evaluate the use of cassava peels added with lactic acid bacteria on the immune organ weight of super native chickens. The material used in this study was 144 Day Old Chick (DOC) super unsex native chicken with an average body weight of $34 \pm 3,14$ gram. The research design used was a completely randomized design (CRD) with a dose of liquid feed additive in the form of a combination of cassava peel flour and lactic acid bacteria mixed with rations. The treatments in this study included T0: basal ration, T1 (basal ration $+10 \%$ feed additive $\mathrm{ml} / \mathrm{kg}$ ), $\mathrm{T} 2$ (basal ration $+15 \%$ feed additive $\mathrm{ml} / \mathrm{kg}$ ) and $\mathrm{T} 3$ (basal ration $+20 \%$ feed additive $\mathrm{ml} / \mathrm{kg}$ ). The parameters observed were body weight, the relative weight of lymph, thymus, and bursa Fabricius superficial chicken stock exchange. The result showed that the combination of cassava peel and lactic acid bacteria had no significant effect $(\mathrm{P}>0.05)$ on body weight, the relative weight of the lymph organs, thymus, and bursa Fabricius of super native chickens. This research concludes that the combination of cassava peel and lactic acid bacteria as a feed additive can maintain chickens' health by not increasing the relative weight of the super native chicken immune organs to the level of $200 \mathrm{ml} / \mathrm{kg}$.
\end{abstract}

Keywords: Super native chicken, cassava peel, lactic acid bacteria, immune organs.

\section{INTRODUCTION}

Super free-range chickens will get promising results both from an economic and social perspective if bred properly, free-range chickens are a cross between female chickens and various types of superior local roosters. The problem in raising native chickens is low feed conversion. Provision of Antibiotic Growth Promoter (AGP) aims to improve feed efficiency and increase livestock growth, but its use is currently prohibited as a feed additive because it can cause antibiotic residues. The provision of AGP can be replaced with other feed additives as a substitute for antibiotics, such as probiotics combined with prebiotics. This combination can increase the increase in non-pathogenic bacteria so that the condition of the digestive tract becomes acidic which will make the digestive tract better.

Cassava peel is one of the waste products from the agro-industry that can be obtained from plantation products. Cassava peel waste contains oligosaccharides, namely $21.20 \%$ crude fiber, $4.80 \%$ crude protein, $1.22 \%$ crude fat, $32.61 \%$ dry matter, $0.36 \%$ calcium, $0.11 \%$ phosphorus, and energy metabolism (EM) of $2960 \mathrm{kcal} / \mathrm{kg}$ (Devendra, 1977). The utilization of cassava peel waste and lactic acid bacteria as additives in the form of feed synbiotics is expected to improve digestibility and the health of livestock's digestive tract so that optimally absorbed nutrients can be utilized by livestock for growth and production (Aryanti et al., 2013). Energy, protein, vitamins, and minerals are nutrients in the ration that are important in the livestock immune system. Protein is indispensable for developing lymphoid organs (Fauci, 2008).

Synbiotics are a combination of probiotics and prebiotics that are used together. The use of synbiotics has the advantage that it can increase the survival of probiotic bacteria due to the specific substrate available for fermentation so that the body gets more perfect benefits (Hamid et al., 2014). In addition, synbiotics are also useful for increasing immunity and production performance in poultry (Murarolli et al., 2014).

This study aims to determine the use of cassava peel and lactic acid bacteria as feed additives in the ration on the relative weight of the immune organs of super-village chickens. The hypothesis of this research is the administration of probiotic Lactobacillus Sp. Different methods can increase the relative weight of immune organs to improve the immune system of super-free-range chickens.

\section{MATERIALS AND METHODS}

The research was conducted in four months at the Poultry Livestock Production Laboratory, Faculty of Animal Husbandry and 
Agriculture, Diponegoro University, Semarang. The analysis of feed ingredients was carried out at the Nutrition and Feed Science Laboratory, Faculty of Animal Husbandry and Agriculture, Diponegoro University, Semarang. Isolation of lactic acid bacteria sp. for the manufacture of feed additives carried out at the Microbiology Laboratory, Faculty of Nursing and Health, University of Muhammadiyah Semarang, Semarang.

The research material was 144 free-range super day-old chicks with an average body weight of $34 \pm 3.14$ grams and unsex reared in 24 cages, equipped with feed and drinking containers with four treatments, six replications, and six birds per unit test.

\section{Manufacture of Cassava Peel}

The making of cassava peel is done by separating the cassava peel from the husk; after that, the white inner skin is washed until clean then cut into smaller sizes, which is about $3-5 \mathrm{~cm}$, then after being cut it is dried in the sun for \pm 3 days. Until dry, the next step is to grind the cassava peels into flour using a grinding machine.

\section{Manufacture of Feed Additives}

The pure isolate was made by taking fresh duck intestine cut into the caecum $\pm 10 \mathrm{~cm}$ then mashed and then put into $4.5 \mathrm{ml}$ of physiological $\mathrm{NaCl}$ and homogenized. Then $0.5 \mathrm{ml}$ were taken for bacterial growth and put into $4.5 \mathrm{ml}$ liquid MRS, stirred to make it homogeneous and then incubated for 24 hours at $37^{\circ} \mathrm{C}$. After that, $0.5 \mathrm{ml}$ of liquid MRS was taken to be diluted 7 times to $107 \mathrm{CFU}$ using $4.5 \mathrm{ml}$ of physiological $\mathrm{NaCl}$. At retailing 106 and 107, they were cultured on MRS agar using ose and incubated for 48 hours at $37^{\circ} \mathrm{C}$ in anaerobic conditions and then calculated the resulting bacterial colony, which was $2.3 \times 10^{8}$ $\mathrm{CFU} / \mathrm{ml}$.

\section{Stage of Application of Treatment}

After being tested for the correct dose, the results of making feed additives and then mixing the two ingredients. The method is to take $100 \mathrm{ml}$ of distilled water, add $10 \% \mathrm{LAB}$ and $6 \%$ cassava peel flour, then homogenize and incubate for 24 hours. Mixing into the ration twice a day, in the morning and evening, was given according to the treatment. The application of feed additive levels in the ration was given at the 4th week of rearing after the adaptation period. The data collection stage was carried out at the rearing period when the cattle were ten weeks old. The treatments applied in this study were as follows:
T0 : basal ration

$\mathrm{T} 1$ : basal ration +100 feed additives $/ \mathrm{kg}$ ration

$\mathrm{T} 2$ : basal ration +150 feed additives $/ \mathrm{kg}$ ration

T3 : basal ration +200 feed additives $/ \mathrm{kg}$ ration

The composition and nutritional content of the feed ingredients used in the study are presented in Table 1.

Table 1. Composition and nutrient content of research ration (on Dry basis)

\begin{tabular}{lc}
\hline Feed Ingredients & Basal Ration $\mathbf{( \% )}$ \\
\hline Corn & 55 \\
bran & 13 \\
Soybean meal & 17 \\
PMM & 11 \\
CaCO3 & 2 \\
Premix & 2 \\
TOTAL & 100 \\
\hline
\end{tabular}

The nutritional content of the ration

$\begin{array}{lc}\text { Energi Metabolic } & 3379 \\ \text { Energy*** } & \\ \text { Protein Content } * * & 18.25 \\ \text { Fat Content } & 3.71 \\ \text { Crude Fiber } & 6.23 \\ \mathrm{Ca} & 1.60 \\ \mathrm{P} & 0.71\end{array}$

Notes:

* Proximate analysis was carried out at the Laboratory of Nutrition and Feed Science, Faculty of Animal Husbandry and Agriculture, Diponegoro University, Semarang (2018)

** Crude Protein Analysis was carried out at the Laboratory of Ecology and Plant Production, Faculty of Animal Husbandry and Agriculture, Diponegoro University, Semarang (2019)

*** Based on the calculation formula with the Balton formula (Siswohardjono, 1982; Melindasari et al., 2014)

EM $(\mathrm{kcal} / \mathrm{kg})=40.81[0.87$ (crude protein $+2.25 \times$ crude fat + BETN $)]+2.5$

\section{Data Collection Stage}

The data collection stage was carried out at the rearing period when the cattle were 10 weeks old. One chicken was taken at random from each experimental unit and then slaughtered and necropsied; then the immune organs were taken from the spleen, thymus, and bursa Fabricius organs. After obtaining the immune organs, the next step is to weigh the immune organs to get the weight of each immune organ. The following formula calculates the relative weight of each organ: 


\section{Relativ Weight}

Relative Weight $=\frac{\text { Organ Weight }}{\text { Body Weight }} \times 100 \%$

\section{Experimental Design}

The experimental design used in this study was a completely randomized design (CRD), with four treatments consisting of 6 replications, each experimental unit containing 6 Kampung Super chickens.

\section{Data Analysis}

The data that has been obtained is then analyzed using ANOVA analysis of variance, after that, it is tested with the F test at a level of $5 \%$ to determine the effect of the experiment, if there is an effect, it is continued with the Duncan test with a level of 5\%. Data analysis was assisted by the SAS program and manual data processing.

\section{RESULT AND DISCUSSION}

\section{Body Weight}

Based on table 2. It shows that the average body weight of chickens in this study is 668.24 $713.31 \mathrm{~g} /$ head. These results indicate that the bodyweight of super native chickens is in the normal range. This is by Winedar et al. (2006) that the average body weight of native chickens until 12 weeks is $710-1752 \mathrm{~g} / \mathrm{h}$ ead. The size of body weight in chickens can be influenced by several factors, namely health conditions and poor maintenance management. According to Salam et al. (2019), good maintenance management, feed consumption, feed quality, sex, and disease influence body weight gain. Considering that maintenance management and feed nutrition have been carried out according to maintenance standards, it is possible that the health of chickens is not in good condition. It is necessary to increase the dose of probiotic Lactobacillus Sp. to affect the increase in body weight of chickens.

The combination treatment of cassava peel and lactic acid bacteria did not affect the bodyweight of super-free-range chickens. This is presumably the presence of anti-nutritional substances in the cassava peel in the form of hydrogen cyanide $(\mathrm{HCn})$. The use of cassava peel continuously will cause health problems in chickens even if given in small amounts. According to Rahmawan and Mansyur (2008), livestock that continuously consume feed containing $\mathrm{HCn}$ below the normal dose can cause health problems. $\mathrm{HCn}$ that is continuously consumed by livestock will be detoxified to affect the process of absorption of feed nutrients and have an impact on the size of the resulting body weight. According to Shofiyana (2017), HCn consumed by the body will be detoxified by binding to sulfur such as methionine and cysteine, decreasing the absorption of feed nutrients. According to Sugiharto et al. (2018), the probiotic Lactobacillus Sp. can produce enzymes that can increase the absorption of feed nutrients in the digestive tract. Feed nutrient is utilized for the growth and development of chickens. According to Kompiang and Supriyati (2001) that the addition of probiotics did not give significant results $(\mathrm{P}>0.05)$ on the bodyweight of broilers.

\section{The Relative Weight of the Spleen}

Table 2 shows that the average relative weight of the spleen in this study is 0.2023 $0.2837 \%$. These results indicate that the relative weight of the spleen of super-free-range chickens is in the normal range. This is by Fajrih et al. (2014) that the relative weight of normal superfree-range chicken spleen is $0.22-0.30 \%$. Lymph is an immune organ that has a role in the maturation and selection of lymphoid cells and plays a role in destroying antigens that enter the body of livestock. According to Muslimy (2016), the spleen forms lymphocyte cells to form antibodies if the food substance given contains toxic, anti-nutritive, and disease substances. Increasing age and excessive activity can affect the development of lymph organs.

Table 2. The relative weight of immune organs of super native chicken ten weeks old

\begin{tabular}{llllll}
\hline \multirow{2}{*}{ Variable } & \multicolumn{4}{c}{ Treatment } & \multirow{2}{*}{ Sig. } \\
\cline { 2 - 5 } & T0 & T1 & T2 & T3 & Ns \\
Body Weight (g) & 668.24 & 713.31 & 686.01 & 696,68 & Ns \\
Spleen (\%) & 0.2101 & 0.2197 & 0.2837 & 0,2023 & Ns \\
Thymus (\%) & 0.4393 & 0.3648 & 0.3210 & 0,3295 & Ns \\
Bursa of Fabricius (\%) & 0.1864 & 0.1502 & 0.2144 & 0,2767 & Ns \\
\hline
\end{tabular}


The size of the spleen can increase or decrease because the spleen is indicated by disease. According to Tarigan et al. (2013), the spleen's disease can cause a reactive process macroscopically so that the organ looks swollen. Etriwati et al. (2017) that swelling that occurs in the lymph organs is a response to incoming infections, so that it stimulates lymphocyte cells in lymphoid organs to form antibodies.

The treatment results showed that the combination of cassava peel and lactic acid bacteria as a feed additive had no impact on the development of the spleen. These results indicate that the condition of the chicken is in good health. According to Jamilah et al. (2013), healthy chickens' health condition is characterized by the lymph organs produced in the normal range or not too large. According to Tarigan et al. (2013) that the addition of cellulosic probiotics did not have a significant effect $(\mathrm{P}>0.05)$ on the relative weight of the spleen. The administration of probiotics that had no significant effect was due to the delayed response of the lymph organs to the effects of probiotics. According to Rais et al. (2015), the method of giving probiotics to native chickens through feed additives does not affect the weight of the spleen because it is a secondary immune organ so that there is an indication of a delayed spleen response to the effects of probiotics.

\section{The relative weight of the thymus}

Based on Table 2, the average relative weight of the thymus in this study was $0.3210-$ $0.4393 \%$. These results indicate that the relative weight of the spleen of super-free-range chickens is within the normal range; according to MoralesLopez et al. (2009), the standard relative weight of the super-free-range chicken spleen is $0.42-$ $0.58 \%$. The thymus is a primary lymphoid organ that has a role in the maturation of lymphoid cells. The normal weight of the thymus indicates that the chickens are in good health and the immune system has not decreased. The reduced size of the thymus can be caused by the increasing age of the chickens and the maturing immune system. Hewajuli and Dharmayanti (2015) that the thymus is an organ for developing $\mathrm{T}$ lymphocytes, whereas we age, the size of the thymus gets smaller and the immune system matures.

The combination treatment of cassava peel and lactic acid bacteria did not affect the relative weight of the thymus of the super-freerange chicken. This is due to the disruption of the health condition of the livestock so that the thymus organ produced does not increase.
According to Sellaoui et al. (2012), giving synbiotics to chickens does not always have an effect; this is because the health condition of the livestock is disturbed so that the organs do not develop. Regards et al. (2013) added that chicken health that is not optimal could result in changes in the size of the thymus organ and also, with increasing age, it can trigger organ failure.

\section{The Relative Weight of the Fabricius bursa}

Based on Table 2, the average relative weight of the Fabricius stock in this study is $0.1502-0.2767 \%$. These results indicate that the relative weight of the super native chicken stock exchange is in the normal range. According to Fajrih et al. (2014), the average relative weight of the super-free-range chicken stock market is 0.12 - $0.33 \%$. Bursa Fabricius is an organ of maturation and differentiation of B lymphocyte cells that has a role to receive and react to foreign objects that enter the livestock body. In addition, bursa Fabricius has a role in forming antibodies in the body. According to Ulupi and Ihwantoro (2014) that B lymphocytes form hormone-specific immunity that produces antibodies.

The results of the combination treatment of cassava peel and lactic acid bacteria did not affect the relative weight of the bursa Fabricius. This is under Montanhini et al. (2013), giving synbiotics does not always affect, depending on how it is used on livestock. Different strains of probiotic bacteria, a dose of use, and the type of chicken used can give different results. Wahyuwardani et al. (2015) added that the presence of pathogenic bacteria in the digestive tract could negatively reduce the number of lactic acid bacteria, resulting in reduced non-pathogenic bacteria, resulting in decreased immunity and chickens are susceptible to disease.

\section{CONCLUSION}

The conclusion is that the application of feed additives in the form of a combination of cassava peel and LAB at the level of administration of 100-200 $\mathrm{ml}$ of feed additives $/ \mathrm{kg}$ ration did not cause changes to the increase in body weight and relative weight of the super native chicken immune organs.

\section{REFERENCES}

Aryanti, F., M. B. Aji dan N. Budiono. 2013. Pengaruh pemberian air gula merah terhadap ayam kampung pedaging. 
Jurnal Sain Veteriner 4 (2): 156 - 165.

Devendra, C. 1977. Cassava as a Feed Source For Ruminant. In: Cassava as Animal Feed. Nestel, B. and M. Graham (Eds). 107 - 119.

Etriwati dan D. Ratih. 2017. Studi hispatologi limfa dan bursa fabrisius ayam penyakit tetelo (Newcastle Disease) pada kasus lapang. J. Veteriner 18 (4): 510-515.

Fajrih, N., N. Suthama and V. D. Yunianto. 2014. Body resistance and productive performance of crossbred local chicken fed inulin of Dahlia tubers. J. Media Peternakan 37 (2): $108-114$

Hamid, I. S., B. P. S. Rahardjo dan M. Gabriela. 2014. Potensi pemberian sinbiotik pada umur yang berbeda pada gambaran histologi ileum ayam pedaging betina. Veterinaria 7(2): 114 - 119.

Hewajuli, D. A. dan N. L. P. I. Dharmayanti. 2015. Peran sistem kekebalan non spesifik dan spesifik pada unggas terhadap newcastle disease. J. Wartozoa 25 (3): 135 $-146$.

Jamilah, N. Suthama dan L. D. Mahfudz. 2013. Performa produksi dan ketahanan tubuh broiler yang diberi pakan step down dengan penambahan asam sitrat sebagai acidifier. J. Ilmu Ternak Veterniner 18 (4): 251 257.

Kompiang, I. P., Supriyati, M. H. Togorop, dan S. N. Jarmani. 2001. Kinerja ayam kampung dengan sistem pemberian pakan secara memilih dengan bebas. J. Ilmu Ternak dan Veteriner $6(2)$ : $94-101$.

Mclelland, J. 1990. Colour Atlas of Avian Anatomy. Walfe Publishing Ltd, London, England.

Montanhini, R.N., M.L. Ceccantini dan J.I.M. Fernandes. 2013 Immune response of broiler fed conventional and alternative diets containing multi-enzyme complex. Brazilian J. of Poul. Sci. 15 (3) : 223-231.

Morales-Lopez, R., E. Auclair, F. Garcia, E. Esteve-Garcia and J. Brufau. 2009. Use of yeast cell walls; $\beta$-1, 3/1, 6-glucans; and mannoproteins in broiler chicken diets. J. Poult. Sci. 88: $601-607$.

Murarolli, D. A., M. F. C. Burbarelli. G. V. Polycarpo, P. A. P. Riberio. M. E. G. Moro, R. Albuequerqe. 2014. Prebiotic, probiotic, and symbiotic an alternative antibiotic on the performances and immune response of broiler chickens. J. Brazilian of Poultry Science 16 (3): 279 - 284.

Muslimy, V. A. 2016. Penggunaan Tepung Daun Mengkudu (Morinda citrifolia) Fermentasi Terhadap Bobot Organ Limfoid dan Ketahanan Tubuh Ayam Kampung Super. Fakultas Peternakan dan Pertanian, Universitas Diponegoro, Semarang. (Skripsi).

Pratikno, H. 2010. Pengaruh Ekstrak Kunyit (Curcuma Domestica Vahl) terhadap Bobot Badan Ayam Broiler (Gallus Sp). J. Buletin Anatomi dan Fisiologi. 18 (2) : 39 - 46.

Qasimah, D., S, Murwani dan A. A. Indah. 2017. Pemyakit Viral pada Unggas. UB Media. Malang.

Raga, N. M., R. M. S. Korany dan F. F. Mohamed. 2016. Effect of dry and formic acid dietary supplementation on broiler performance and immunity. Agriculture and Agriculture Science Procedia 10: 270 - 279.

Rahmawan, O. dan Mansyur. 2008. Detoksifikasi HCN dari Bungkil Biji Karet (BBK) melalui berbagai perlakuan fisik. Prosiding Seminar Nasional Teknologi Peternakan dan Veteriner. Bogor, 13 - 14 Agustus 2008. Puslitbang Peternakan, Bogor. Hal : $789-796$.

Rais, S.I.A., M.Y. Fajar, A.S. Wibowo, M.R. Fatah, I. Isroli, T. Yudiarti dan S. Sugiharto. 2015. Bobot organ imun ayam kampong umur 30 hari akibat penambahan probiotik fungi Rhizopus oryzae dalam ransum. Prosiding Seminar Nasional Peternakan Berkelanjutan. Hal. 128-286.

Rasyaf, M. 1989. Memelihara Ayam Buras. Kanisius. Yogyakarta.

Salam, D. B., U. Ali dan M.F. Wadjdi. 2019. Pengaruh penggunaan campuran gaplek 
dan ampas tahu terfermentasi Trichoderma viride sebagai subtitusi pakan komersial terhadap konsumsi pakan dan pertambahan bobot badan pada broiler finisher. $\mathrm{J}$. Rekasatwa 1 (1) : 48-52.

Sellaoui, S., N. Alloui, S. Mehenaoui dan S. Djaaba. 2012. Evaluation of size and lesion scores of bursa cloacae in broiler flocks in Algeria. J. World's Poult. Res. 2 (2): 37-39.

Shofiyana, A. 2017. Profil dan Metabolit Darah Domba Disuplementasi Bakteri Pendegradasi HCn dan Sulfur pada Pakan Mengandung Tepung Daun Singkong Pahit. Fakultas Peternakan Institut Pertanian Bogor, Bogor. (Skripsi).

Sugiharto, S., T. Yudiarti., I. Isroli and E. Widiastuti. 2018. Effect of feeding duration of Spirulina platensis on growth performance, hematological parameters, intestinal microbial population, and carcass traits of broiler chicks. J. Animal Science 48 (1): $98-107$.

Tarigan, R., O. Sjofjan., dan I. H. Djuaidi. 2013. Pengaruh penambahan probiotik selulotik (Cellulomunas sp) dalam pakan terhadap kualitas karkas, lemak abdominal dan berat organ dalam ayam pedaging. $1-10$.

Ulupi, N. dan T. T. Ihwantoro. 2014. Gambaran darah ayam kampung dan ayam petelur komersial pada kandang terbuka di daerah tropis. J. Ilmu Produksi dan Teknologi Hasil Peternakan 2 (1): 219 - 223.

Wahyuwardani, S., D.R.A. Priyono dan W. Manalu. 2015. Gambaraan patologi bursa fabricius ayam pasca vaksinasi secara in vivo menggunakan vaksin lokal dan komersial. J. Vet. 16 (3) : 399-408.

Wijaya, G. H. 2010. Persentase Karkas, Lemak Abdominal dan Organ Dalam Ayam Broiler yang Diberi Ransum dengan Penambahan Cassabio. Fakultas Peternakan, Institut Pertanian Bogor. Skripsi.

Winedar, H., S. Listyawati dan Sutarno. 2006. Daya cerna protein pakan, kandungan protein daging dan pertambahan berat badan ayam broiler setelah pemberian pakan yang difermentasi dengan Effective Microorganism-4 (EM-4). Jurnal Bioteknologi 3 (1): 14-19. 